\title{
The Application of Classroom Teaching Implementation of Chinese Painting in Primary and Secondary Schools in Art Teachers' Teaching Strategies
}

\author{
Xiujie $\mathrm{Wu}^{1}$, Huangyun $\mathrm{Wu}^{2}$, Wen-Lung Chang ${ }^{3 *}$, Guanglin Zeng ${ }^{{ }^{*}}$ \\ ${ }^{1}$ Fujian Institute of Education, Fuzhou, China \\ ${ }^{2}$ School of Education Science, Nanning Normal University, Nanning, China \\ ${ }^{3}$ Fujian Economic School, Fuzhou, China \\ *Corresponding Author.
}

\begin{abstract}
:
In this study, 420 primary and secondary school art teachers from many primary and secondary schools in Fujian were selected as the research objects. There are three survey methods involved in this paper, which are teacher interview, student questionnaire and classroom observation, among which classroom observation mainly refers to students' listening activities in the class of fine arts and traditional Chinese painting, understanding the classroom situation of fine arts and traditional Chinese painting teaching, and mastering students' response, while teacher interview is an empirical study of interview investigation based on art teachers' voluntary participation. This study reveals that (1) Attaching importance to the appreciation of traditional Chinese painting and stimulate interest in learning. (2) Enriching teaching methods and actively guiding. (3) Carrying out demonstration teaching to stimulate creativity.
\end{abstract}

Keywords: Classroom teaching, Art teacher, Teaching strategies, Chinese painting, Primary and secondary schools

\section{RESEARCH BACKGROUND}

After the promulgation of China's Art Curriculum Standard for Full-time Compulsory Education (referred to as "Curriculum Standard") in 2011, domestic teachers and scholars have extensively discussed the teaching of Chinese painting in primary school art classes from the aspects of methods, values and status[1]. The interpretation of "Curriculum Standard" reveals 
that the significance of art education is becoming more and more important under the background of the new era, that is, attaching importance to humanism, cultivating students' innovative ability and imagination, etc., all of which emphasize the use of new forms, new contents and new concepts to construct art education [2]. At the same time, under the background of continuous innovation and development in the new era, talents come forth in large numbers and new phenomena emerge in endlessly in the Chinese painting circle of our country. In addition, the appearance of realistic meticulous painting, conceptual ink painting, new ink painting, new literati paintings and other artistic forms and concepts have gradually surpassed the traditional Chinese painting and promoted the development of Chinese painting to a certain extent. However, the traditional and backward teaching methods of traditional Chinese painting are still adopted in the art classroom of primary and secondary schools. And for a long time, appreciating the masterpieces of traditional Chinese painting masters and practicing painting with pen, ink, paper and ink-stone are the main solidified contents in Chinese painting education [3]. There are many problems in the teaching of traditional Chinese painting in primary and secondary schools, such as single evaluation, separation from life, simple imitation and conformism, etc., which lead to students' low enthusiasm for learning and poor classroom teaching quality[4]. In order to meet the development needs of the times, the spirit of the New Curriculum Standard should be taken as the basic premise in Chinese painting teaching, and the concepts, principles and properties of Chinese painting teaching in primary and secondary schools should be systematically and comprehensively combed, and innovations should be made in the teaching process, so as to build a new and vital teaching system of fine arts and Chinese painting in primary and secondary schools [5]. Therefore, on the basis of understanding the current situation of Chinese painting classroom teaching in primary and secondary schools, effective teaching strategies are proposed in this paper to promote the improvement of Chinese painting classroom teaching in primary and secondary schools, as shown in the following.

\section{METHODOLOGY}

\subsection{Research Object}

In this study, 420 primary and secondary school art teachers from many primary and secondary schools in Fujian were selected as the research objects, aged from 22 to 47 years, with an average age of (34.2 \pm 7.1$)$, of which 200 were female and 220 were male, as shown in Fig. 1. 190 questionnaires were distributed among students, and 175 valid questionnaires were recovered, with a recovery rate of $92.11 \%$. 


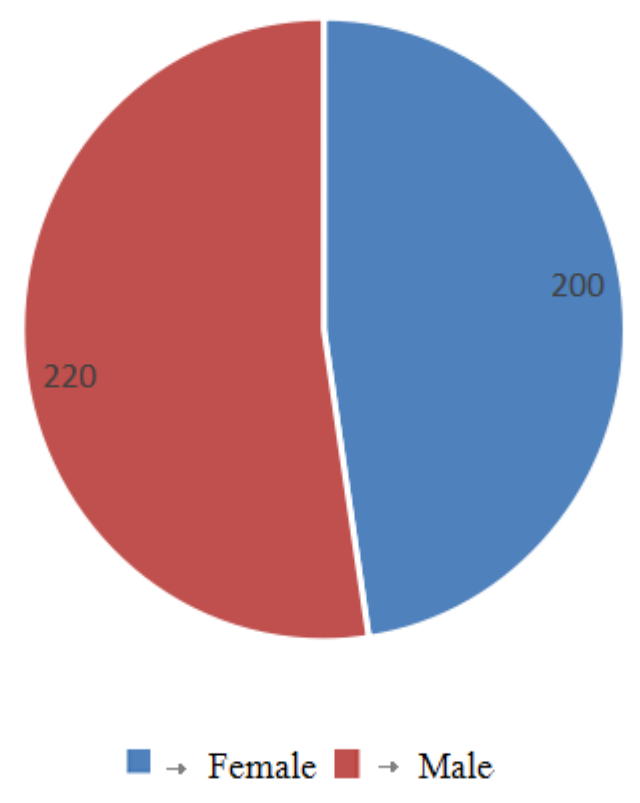

Fig 1: Gender distribution

\subsection{Research Process}

\subsubsection{Survey methods}

There are three survey methods involved in this paper, which are teacher interview, student questionnaire and classroom observation, among which classroom observation mainly refers to students' listening activities in the class of fine arts and traditional Chinese painting, understanding the classroom situation of fine arts and traditional Chinese painting teaching, and mastering students' response, while teacher interview is an empirical study of interview investigation based on art teachers' voluntary participation.

\subsubsection{Statistical analysis}

The data of this study were imported into Excel table for preliminary screening and processing, and analyzed by SPSS20.0 software, in which the counting data was expressed by percentage $(\%)$, and the rank sum test showed that it was statistically significant with $\mathrm{P}<0.05$.

\subsection{Research Tools}




\subsubsection{Student questionnaire}

The Questionnaire for Primary School Students' Learning Chinese Painting in Classroom on the professional questionnaire website was selected, which is composed of two parts, one part is based on the students' basic information, including 1 and 2 questions, and the other part is a survey on the study of traditional Chinese painting, including 3-8 questions covering three dimensions, namely, teaching suggestions, study and interest in traditional Chinese painting, as shown in Table 1.

TABLE I Questionnaire for Primary School Students' Learning Chinese Painting in Classroom

\begin{tabular}{|c|c|c|}
\hline $\mathbf{S} / \mathbf{N}$ & QUESTIONS & ITEMS \\
\hline 1 & Gender & A. Male B. Female \\
\hline 2 & Grade & $\begin{array}{l}\text { A. Primary school; B. } \\
\text { Secondary school }\end{array}$ \\
\hline 3 & $\begin{array}{l}\text { Do you know anything } \\
\text { about Chinese painting? }\end{array}$ & $\begin{array}{l}\text { A. Yes; B. More or less; C. } \\
\text { No }\end{array}$ \\
\hline 4 & $\begin{array}{l}\text { Would you like to study } \\
\text { Chinese painting? }\end{array}$ & $\begin{array}{l}\text { A. Yes, very much; B. } \\
\text { Interested; C. It doesn't } \\
\text { matter; D. No }\end{array}$ \\
\hline 5 & $\begin{array}{l}\text { Do you like Chinese } \\
\text { painting? }\end{array}$ & A. Yes; B. General; C. No \\
\hline 6 & $\begin{array}{l}\text { Do you want to take } \\
\text { Chinese painting class? }\end{array}$ & $\begin{array}{l}\text { A. Yes, very much; B. } \\
\text { General; C. It doesn't } \\
\text { matter; D. No }\end{array}$ \\
\hline 7 & $\begin{array}{l}\text { How would you like to } \\
\text { take the traditional } \\
\text { Chinese painting class if } \\
\text { you were in charge? }\end{array}$ & \\
\hline 8 & What do you want to say & \\
\hline
\end{tabular}


Article History: Received: 28 October 2021 Revised: 05 December 2021 Accepted: 10 January 2022 Publication: 28 February 2022

\begin{tabular}{|l|l|}
\hline & $\begin{array}{l}\text { to the teacher about } \\
\text { Chinese painting class? }\end{array}$
\end{tabular}

\subsubsection{Teacher interview}

On the premise of voluntary participation, interview and study teachers, including the following questions: (1) What are your real feelings in the teaching of Chinese painting in art class? (2) Do you think more demonstrations should be given to students in teaching? (3) What do you think are the problems in the teaching of traditional Chinese painting in art classes in primary and secondary schools? (4) Have you improved the problems in traditional Chinese painting teaching during your teaching? (5) How do you think to solve this situation? (6) Have you put all these ideas into practice?

\section{RESULTS}

\subsection{Basic Information of Students}

The answer of most students to the question "Do you want to take Chinese painting lessons?" is "Yes, very much", followed by "general", "It's doesn't matter" and "No", as shown in Fig. 2. At the same time, the survey results of the students are shown in Table 2 for the question "How would you like to take the traditional Chinese painting class if you were in charge?"

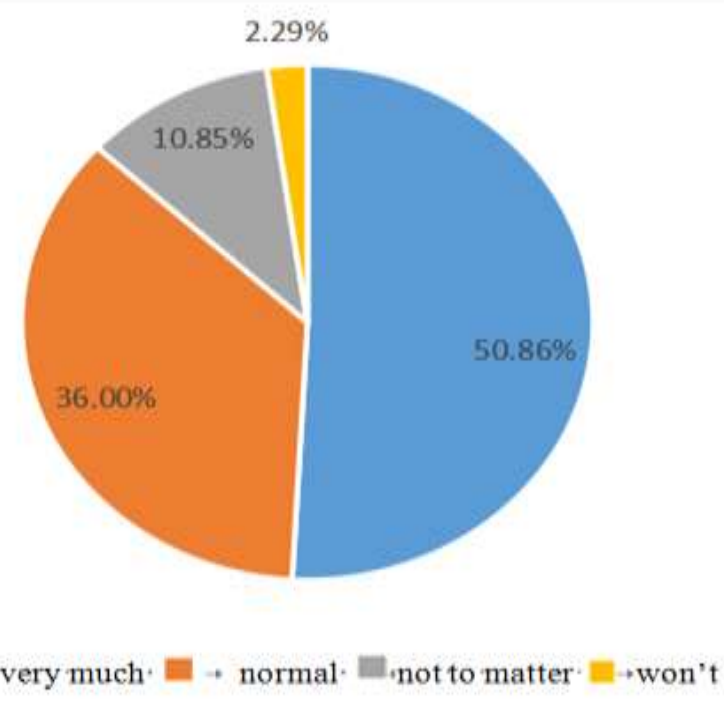


Fig 2: The answer of most students to the question "Do you want to take Chinese painting lessons?"

TABLE II Distribution of students' opinions on traditional Chinese painting class

\begin{tabular}{|l|l|l|}
\hline $\begin{array}{l}\text { METHODS OF } \\
\text { CHINESE PAINTING } \\
\text { COURSE }\end{array}$ & $\begin{array}{l}\text { NUMER OF CASES } \\
(\mathbf{N})\end{array}$ & PERCENTAGE (\%) \\
\hline APPRECIATION & 29 & 16.57 \\
\hline IMITATION & 45 & 25.71 \\
\hline PAINTING FROM LIFE & 93 & 53.14 \\
\hline NOT TO MATTER & 8 & 4.57 \\
\hline TOTAL & 175 & 100.0 \\
\hline
\end{tabular}

\subsection{Teacher Interview}

The survey found that there are still many problems in the current classroom teaching of Chinese painting in primary and secondary schools, including teachers' lack of correct understanding of the teaching significance of Chinese painting, improper teaching methods of Chinese painting, and stylized or copy model teaching, etc. see Table 3

Table III Distribution of problems in classroom teaching of Chinese painting in primary and secondary schools

\begin{tabular}{|c|c|c|}
\hline EXISTING PROBLEMS & $\begin{array}{l}\text { NUMBER OF CASES } \\
(\mathrm{N})\end{array}$ & PERCENTAGE (\%) \\
\hline $\begin{array}{l}\text { Lack of correct } \\
\text { understanding of the } \\
\text { teaching significance of } \\
\text { Chinese painting }\end{array}$ & 76 & 18.10 \\
\hline
\end{tabular}


Article History: Received: 28 October 2021 Revised: 05 December 2021 Accepted: 10 January 2022 Publication: 28 February 2022

\begin{tabular}{|l|l|l|}
\hline $\begin{array}{l}\text { Improper teaching } \\
\text { methods of Chinese } \\
\text { painting }\end{array}$ & 158 & 37.62 \\
\hline $\begin{array}{l}\text { Stylized or copy model } \\
\text { teaching }\end{array}$ & 186 & 44.29 \\
\hline Total & 420 & 100.0 \\
\hline
\end{tabular}

\section{DISCUSSIONS}

It is mentioned in Curriculum Standard (Experimental Draft) that curriculum reform is not only to reform the content, but also to reform the teaching method and process, especially the teaching method and process, which is also an important feature of curriculum reform. "[6,7] This study reveals that there are still many problems in the teaching of traditional Chinese painting by art teachers in primary and secondary schools, including: (1) lack of correct understanding of the teaching of traditional Chinese painting. During the interview, it was found that some teachers mainly copied books in the process of teaching. Although this is easy to operate and the classroom effect is outstanding, it is rather dull and boring, which results in students' low enthusiasm and initiative[8], which to a certain extent also reflects the lack of understanding of teaching materials by art teachers in regular teaching and is also a wrong interpretation of teaching materials[9]. The research shows that when learning Chinese painting, copy in is only a means rather than the only way to learn[10]. (2) Improper teaching methods. In the research, some teachers think that the single teaching method of traditional Chinese painting is an important reason for the students' lack of interest in learning, because the students know less about traditional Chinese painting, while the teachers adopt the method of teaching copying one by one, which is rather boring in content and reduces the students' learning enthusiasm[11]. At the same time, it is also found in the students' questionnaire that most students hope that teachers can teach Chinese painting flexibly[12]. Therefore, art teachers in primary and secondary schools should adjust their teaching methods and fully mobilize students' learning enthusiasm and initiative through various teaching forms. (3) Stylized or copy model teaching. The current teaching of Chinese painting usually shows the state of stylization and copying templates, but the author believes that this is a misunderstanding of Chinese painting by contemporary people[13], because Chinese painting teaching not only teaches painting techniques, but also cultivates one's morality and cultivates one's sentiments and inherits traditional culture. In addition, attention should be paid to students' appreciation of Chinese painting works to cultivate their interest in Chinese painting so as to improve their appreciation ability $[14,15]$. According to the above problems, the primary and secondary school art teachers can start with the following aspects when carrying 
out the traditional Chinese painting teaching: (1) attaching importance to the appreciation of traditional Chinese painting and stimulate interest in learning. In the teaching of Chinese painting, Chinese painting appreciation is a key link to fully stimulate students' love of traditional culture and Chinese painting, so as to cultivate students' interest, and it can also promote the improvement of students' aesthetic taste and cultural quality in the process of appreciation[16]. (2) Enriching teaching methods and actively guiding. Art teachers should adopt various teaching methods, change the traditional single and boring teaching methods, and be good at stimulating students' creativity, among which the exploration of problems is a direct source of creativity[17]. (3) carrying out demonstration teaching to stimulate creativity. Because traditional Chinese painting techniques have complex and diverse characteristics, and contain profound cultural background, it is particularly important for teachers to demonstrate and demonstrate correctly when students understand these cultures[18]. For example, teachers can demonstrate various color-using techniques with pens on rice paper in the classroom, such as color-blowing, color-spotting, water-hitting, color run, paint-splashing, etc., to satisfy students' curiosity and stimulate their interest in learning [19-20].

\section{CONCLUSIONS}

To sum up, there are still many problems in the classroom teaching of Chinese painting by art teachers in primary and secondary schools, which are not conducive to cultivating students' interest in learning and reduce the quality of classroom teaching. Therefore, teachers should constantly improve classroom teaching mode on the basis of correct understanding of traditional Chinese painting, fully stimulate students' learning enthusiasm and initiative, and give play to the leading position of classroom teaching, thus promoting the improvement of classroom teaching level.

\section{REFERENCES}

[1] Wen YF. Exploration on teaching strategies of elementary school art traditional Chinese painting. Learning Weekly, 2021 (19): 157-158.

[2] Dai FQ, Zhao HY. Aesthetic perspective: Teaching strategies of Chinese painting expression based on art performance literacy. Art Education Research, 2021(08): 148-149.

[3] Kui L (2021). Analysis of the application skills of color in the creation of characters in traditional Chinese painting. Frontiers in Art Research, 3(1):223-224.

[4] Yan J (2020). An analysis of the system of Chinese contemporary art history theory based on the continuation of traditional painting study context. International Journal of Education and Teaching Research, 1(4):101-102.

[5] Li WQ (2020). On the recursion of syntax and discourse structure in linguistics and the recursion of Chinese traditional landscape painting. Arts Studies and Criticism, 1(2): 40-42. 
[6] Zhang X. Exploration on the cultivation of core competence of traditional Chinese painting teaching in art education major of higher vocational colleges. Panorama of Chinese Nationalities, 2020(16): 23-24.

[7] Yan F. Teaching strategies of Chinese painting in elementary art course. Daylight Science for Kids (teaching research), 2020(01): 159.

[8] Li L. Teaching and research of Chinese painting in the art course of primary school. Art Education Research, 2019(24): 152-153.

[9] Xia QT. An analysis of teaching strategies of elementary art traditional Chinese painting. Foundations of Educational Research, 2019(20): 87-88.

[10] Wang QZ. Preliminary study on teaching strategies of Chinese painting in junior middle school art classes. Daguan (Forum), 2019(09): 194-195.

[11] Zhang L. Teaching strategies of Chinese painting in elementary school art course. Cathay Teacher, 2019(27): 59.

[12] Liu H. Reflections on the fusion of primary school art traditional Chinese painting teaching and core literacy concepts. Guide to Knowledge, 2019(34): 60-61.

[13] Chen L. Teaching strategy of elementary Chinese painting micro-lessons based on self-study. Education Circle (teacher training), 2019(06): 76-77.

[14] Zhang YY. Teaching strategies of Chinese painting in elementary art courses. Artists of China, 2019(03): 177.

[15] Ding XC. On the teaching strategies of Chinese painting in junior middle school art courses. Inner Mongolia Education, 2019(03): 49-50.

[16] Lu X (2019). Exploration on the fusion of traditional Chinese painting teaching and core literacy concepts in elementary art. Reading and Writing (Educational and Teaching Journal), 16 (01): 198.

[17] Yu XJ. Teaching strategies of Chinese painting in elementary art courses. Learning Weekly, 2018(30): 156-157.

[18] Xie Y. Inheriting Chinese painting and promoting traditions--a brief discussion on the teaching strategy of Chinese painting in middle schools. Art Education Research, 2018(10): 138.

[19] Xu XZ. Teaching strategies to cultivate primary school students' interest in Chinese painting under core literacy. Course Education Research, 2018(04): 202-203.

[20] Liu YW. Teaching strategies of creative Chinese painting for children. Journal of the Chinese Society of Education, 2016(S2): 41-44. 